\title{
Forceps-assisted technique: a new technique for difficult cannulation
}

Endoscopic retrograde cholangiopancreatography (ERCP) is one of the options for the treatment of several pancreaticobiliary pathologies and deep cannulation of the common bile duct (CBD) via the major papilla is the first step for a successful ERCP. Cannulation of the major papilla can however be a challenge as selective biliary cannulation reportedly fails in up to $18 \%$ of cases, although this failure rate falls to less than $5 \%$ in experienced hands [1]. Several techniques have been proposed to facilitate cannulation, such as the double-guidewire technique, infundibulotomy, pancreatic duct stenting, and transpancreatic precut [2,3].

- Video 1 shows one of four patients who benefited from a new technique: the forceps-assisted technique (FAT), which involves the use of two devices in the same working channel to facilitate cannulation of the major duodenal papilla. The objective of the technique is to hold the papilla at its base to straighten the distal " $\mathrm{S}$ " shape of the intrapancreatic portion of the CBD. The procedure was achieved with a duodenoscope (Fujinon ED-530XT8; working channel $4.2 \mathrm{~mm})$. The devices used were a sphincterotome (Rota Cut; Medi-Globe, Germany) loaded with a 0.018-inch guidewire (Easy Way Guidewire; Life Partners Europe, Germany) and a pediatric biopsy forceps (Fujinon; $1.8 \mathrm{~mm}$ ), which were jointly advanced into the working channel. The papilla base was grasped and pushed down and the cannulation was performed by advancing the tip of the sphincterotome toward the papilla orifice and bending the cutting wire of the sphincterotome ( Fig.1). The cannulation was achieved in less than 10 minutes ( $\mathbf{F i g . 2}$ ).

In conclusion, the forceps-assisted technique using a pediatric forceps that is jointly introduced with the sphincterotome to hold the base of the papilla

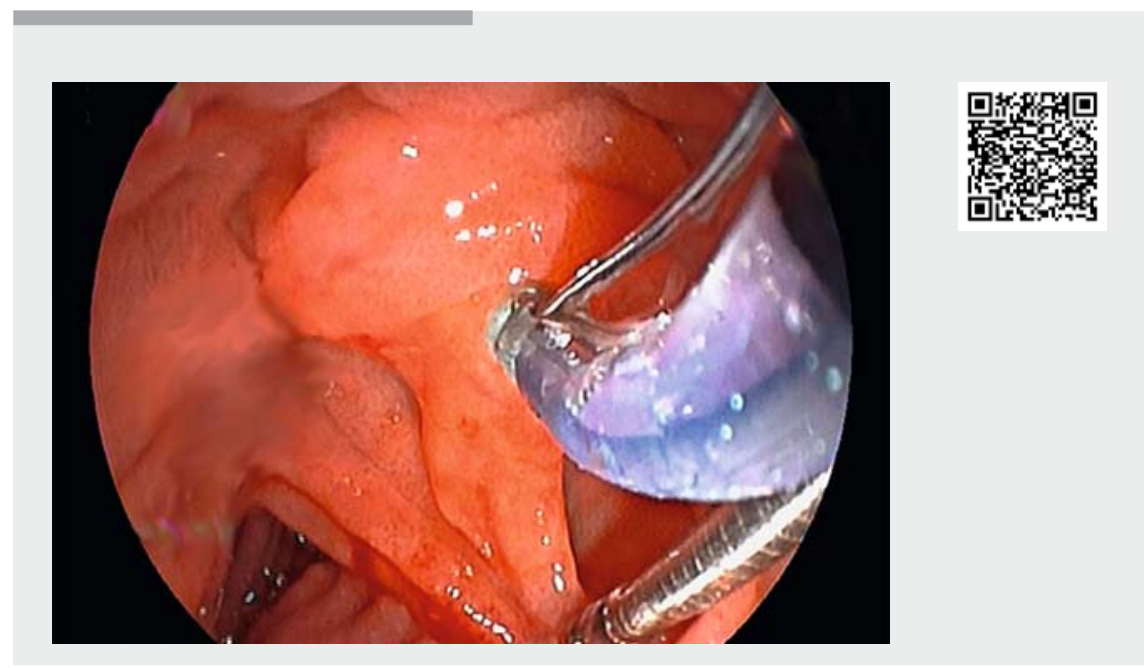

Video 1 The forceps-assisted technique is used to perform a difficult cannulation.

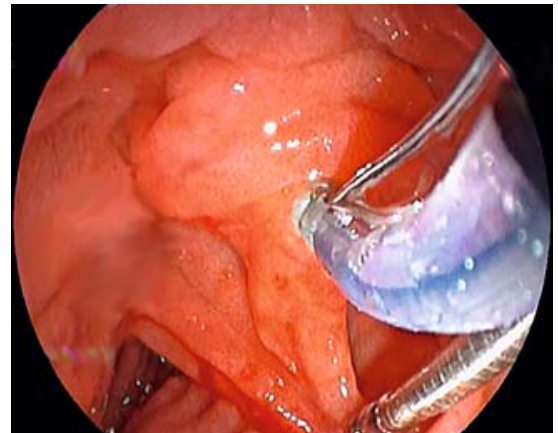

- Fig. 1 Endoscopic view showing the sphincterotome and a pediatric forceps emerging from the working channel.

seems to be a very interesting and safe technique to facilitate cannulation and should be integrated into the technical arsenal for difficult cannulation of the CBD.

Endoscopy_UCTN_Code_TTT_1AR_2AK

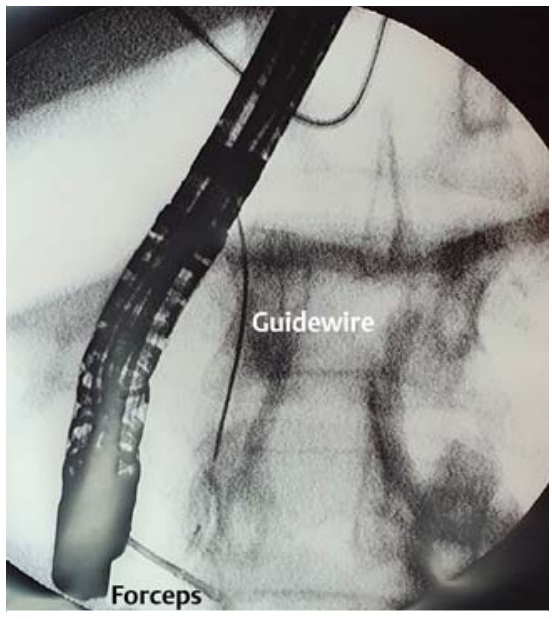

- Fig. 2 Fluoroscopic view showing successful cannulation of common bile duct with the forceps-assisted technique.

\section{Competing interests}

The authors declare that they have no conflict of interest. 
The authors

Mohamed Borahma, Imane Benelbarhdadi, Camellia Berhili, Nawal Lagdali, Fatima Zahra Ajana

Department of Gastroenterology C, Ibn Sina Hospital, Mohammed the Vth University, Rabat, Morocco

Corresponding author

Mohamed Borahma, MD

Mohammed the Vth University, Ibn Sina Hospital, Department of Gastroenterology C, Rabat, Morocco

borahmamed@gmail.com
References

[1] Testoni PA, Mariani A, Aabakken L et al. Papillary cannulation and sphincterotomy techniques at ERCP: European Society of Gastrointestinal Endoscopy (ESGE) Clinical Guideline. Endoscopy 2016; 48: 657-683

[2] Kim CW, Chang JH, Kim TH et al. Sequentia double-guidewire technique and transpancreatic precut sphincterotomy for difficult biliary cannulation. Saudi J Gastroenterol 2015; 21: 18-24

[3] Dumonceau JM, Deviere J, Cremer M. A new method of achieving deep cannulation of the common bile duct during endoscopic retrograde cholangiopancreatography. Endoscopy 1998; 30: S80

\section{Bibliography}

DOI https://doi.org/10.1055/a-1089-7418

Published online: 29.1.2020

Endoscopy 2020; 52: E247-E248

(c) Georg Thieme Verlag KG

Stuttgart · New York

ISSN 0013-726X

\section{ENDOSCOPY E-VIDEOS \\ https://eref.thieme.de/e-videos}

回回 Endoscopy E-Videos is a free access online section, reporting 回: on interesting cases and new techniques in gastroenterological endoscopy. All papers include a high quality video and all contributions are freely accessible online.

This section has its own submission website at https://mc.manuscriptcentral.com/e-videos 